\title{
COLLABORATIVE GOVERNANCE PENANGANAN HIV AIDS DI PROVINSI DKI JAKARTA
}

\author{
Agung Rheza Fauzi, Amy Yayuk Sri Rahayu \\ Program Studi Administrasi dan Kebijakan Publik \\ Fakultas Ilmu Administrasi Universitas Indonesia
}

agung.rheza@gmail.com

\begin{abstract}
Abstrak
Collaborative Governance merupakan suatu bentuk susunan pemerintahan dimana satu atau lebih instansi publik secara langsung berhubungan dengan pemangku kepentingan non negara dalam sebuah proses pengambilan keputusan yang formal, berorientasi pada konsensus, deliberatif, dan menuju pada formulasi atau implemetasi kebijakan publik, atau dapat pula berbentuk manajemen program atau aset publik. Collaborative Governance menjadi salah satu upaya Pemerintah Provinsi DKI Jakarta untuk menangani kasus HIV AIDS yang terus meningkat. Penelitian ini dilakukan untuk menganalisis proses kolaborasi penanganan HIV AIDS di Provinsi DKI Jakarta. Selain itu, penelitian ini bertujuan untuk memberikan rekomendasi strategis tata kelola kolaboratif yang efektif dalam rangka penanganan HIV AIDS. Penelitian ini menggunakan metode penelitian kualitatif deskriptif dengan menggunakan teknik pengumpulan data melalui wawancara dan studi literatur. Hasil dari penelitian ini menunjukan bahwa proses tata kelola kolaboratif penanganan HIV AIDS di DKI Jakarta secara umum sudah berjalan dengan baik, namun terdapat beberapa hal yang perlu ditingkatkan untuk mendorong proses tata kelola kolaboratif para aktor, antara lain perlunya meningkatkan intensitas pertemuan antar aktor dan meningkatkan peran kepemimpinan (leadership) Komisi Penanggulangan AIDS sebagai lembaga kolaboratif penanganan HIV AIDS di Provinsi DKI Jakarta. Penelitian ini diharapkan memperkaya kajian akademis tentang tata kelola kolaboratif dalam ranah kebijakan publik dan dapat digunakan sebagai acuan bagi pihak yang ingin memberikan sumbangsih terkait penanganan HIV AIDS dengan cara berkolaborasi dengan pemerintah.
\end{abstract}

Kata Kunci : HIV AIDS, Collaborative Governance, Dinamika Kolaborasi

\begin{abstract}
Collaborative Governance is a form of government arrangement in which one or more public agencies directly relate to non-state stakeholders in a formal decision-making process, oriented to consensus, deliberative, and towards the formulation or implementation of public policy, or can be in the form of program management or public assets. Collaborative Governance is one of the efforts of the DKI Jakarta Provincial Government to handle HIV AIDS cases that continue to increase. This research was conducted to analyze the collaborative process of handling HIV AIDS in DKI Jakarta Province. In addition, this study aims to provide strategic recommendations for effective collaborative governance in the context of handling HIV AIDS. This study uses descriptive qualitative research methods by using data collection techniques through interviews and literature studies. The results of this study indicate that the process of collaborative governance of handling HIV AIDS in DKI Jakarta in general has gone well, but there are several things that need to be improved to encourage the collaborative governance process of actors, including the need to increase the intensity of meetings between actors and enhance roles leadership (leadership) of the AIDS Commission as a collaborative institution handling HIV AIDS in DKI Jakarta Province. This research is expected to enrich academic studies of collaborative governance in the realm of public policy and can be used as a reference for those who wish to contribute in handling HIV AIDS by collaborating with the government.
\end{abstract}

Keywords : HIV AIDS, Collaborative Governance, Dynamic Collaborative 


\section{A. PENDAHULUAN}

Penyakit HIV AIDS merupakan permasalahan kesehatan yang perlu ditangani secara maksimal, tidak hanya melalui sisi kesehatan saja namun juga melalui peran dari para stakeholder pemerintah maupun non pemerintah. Data Direktorat Jenderal Pencegahan dan
Pengendalian Penyakit Kementerian Kesehatan Republik Indonesia menunjukan bahwa Provinsi DKI Jakarta merupakan provinsi dengan jumlah infeksi HIV paling banyak yaitu sebesar 51.981 kasus infeksi HIV yang dilaporkan. Hal ini dapat dilihat melalui tabel berikut :

\section{Tabel 1. Perkembangan Kasus HIV-AIDS di Prov. DKI Jakarta s.d. Tahun 2017}

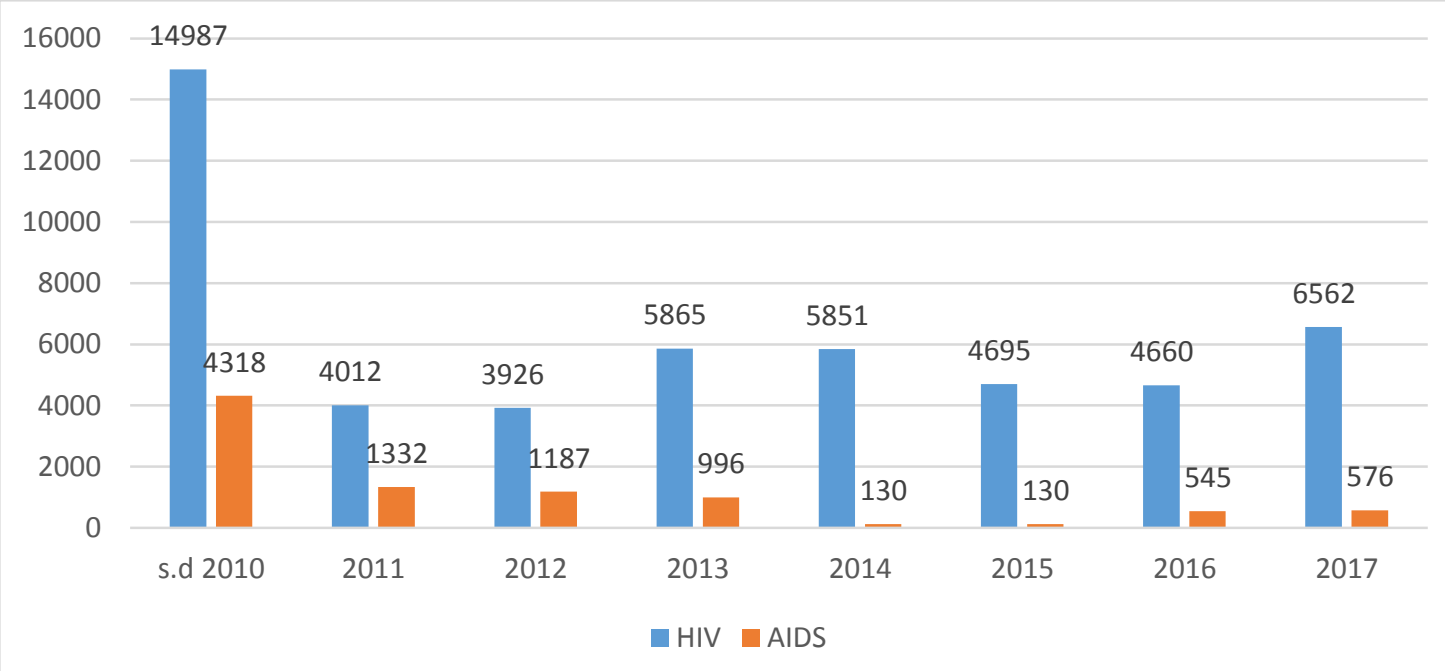

Sumber : Dinas Kesehatan Provinsi DKI Jakarta, 2018

Pemerintah sebagai aktor yang berkewajibanmelakukan penanggulangan HIV AIDS tidak dapat melakukan perannya sendiri sehingga membutuhkan kolaborasi dengan aktor lain. Oleh karena itu, terdapat penggunaan konsep tata kelola kolaborasi atau collaborative governance. Collaborative governance adalah perjanjian atau kerjasama dimana agen publik dan stakeholders non pemerintah dalam proses pembuatan keputusan kolektif yang bersifat formal, berdasarkan konsensus, dan bersifat deliberative yang bertujuan membuat atau mengimplementasikan kebijakan publik, atau manajemen program / aset publik (Ansell \& Gash, 2007:544).

Pemerintah Provinsi DKI Jakarta, melalui Peraturan Daerah Nomor 5 Tahun 2008 tentang Penanggulangan HIV dan AIDS, berupaya untuk menekan laju penularan HIV dan AIDS. Upaya penanggulangan ini melibatkan pemerintah, masyarakat serta sektor terkait lainnya (Pasal 5). Peraturan Daerah ini juga menjadi dasar lahirnya Komisi Penanggulangan AIDS Provinsi DKI Jakarta (KPAP) pada tingkat 
Provinsi dan Komisi Penanggulangan AIDS Kota/Kabupaten (KPAK) pada tingkat Kota/Kabupaten Administrasi. Program pencegahan HIV/AIDS di Provinsi DKI Jakarta memerlukan peran serta lintas sektor, sehingga melalui Keputusan Wakil Gubernur Provinsi DKI
Jakarta selaku Ketua Komisi Penanggulangan AIDS Provinsi DKI Jakarta Nomor 62/KPAP-DKI/VIII/07 dibentuklah Kelompok Kerja (Pokja) Program Penanggulangan HIV/AIDS di Provinsi DKI Jakarta yang terdiri dari :

\section{Tabel 2. Kelompok Kerja dalam Struktur KPAP DKI Jakarta}

\begin{tabular}{|c|c|c|}
\hline No & Nama Pokja & Sektor / Instansi \\
\hline 1 & Pokja Harm Reduction (HR) & Dinas Kesehatan \\
\hline 2 & Pokja Remaja & Dinas Pendidikan \\
\hline 3 & Pokja Transmisi Seksual & Dinas Sosial \\
\hline 4 & Pokja Masyarakat Umum & $\begin{array}{l}\text { Badan Pemberdayaan Masyarakat, Perempuan dan } \\
\text { Keluarga Berencana (BPMPKB) - sekarang Dinas } \\
\text { Pemberdayaan Perlindungan Anak dan } \\
\text { Pengendalian Penduduk }\end{array}$ \\
\hline 5 & $\begin{array}{l}\text { Pokja PMTCT (Pencegahan } \\
\text { Penularan Ibu ke Anak) }\end{array}$ & $\begin{array}{l}\text { Badan Pemberdayaan Masyarakat, Perempuan dan } \\
\text { Keluarga Berencana (BPMPKB) - sekarang Dinas } \\
\text { Pemberdayaan Perlindungan Anak dan } \\
\text { Pengendalian Penduduk }\end{array}$ \\
\hline 6 & Pokja Tenaga Kerja & Dinas Tenaga Kerja dan Transmigrasi \\
\hline 7 & Pokja Lapas \& Rutan & Kanwil Kementerian Hukum dan HAM \\
\hline 8 & Pokja Pelabuhan Tanjung Priok & Administrator Pelabuhan Utama Tj. Priok \\
\hline 9 & Pokja Agama & Kanwil Kementerian Agama DKI Jakarta \\
\hline
\end{tabular}

Sumber : KPA Provinsi DKI Jakarta

Pokja - Pokja ini bertugas untuk membantu mengembangkan program yang sesuai dengan kebutuhan, membantu menggerakan stakeholder / pemangku kepentingan dalam mengaplikasikan kebijakan daerah untuk suatu program, membantu melaksanakan mentoring, motivasi, advokasi, fasilitasi dan supervisi, serta melaporkan hasil kegiatan kepada Ketua KPAP melalui Sekretaris KPAP secara periodik. Pembiayaan kegiatan pokja ini bersumber dari anggaran hibah Pemerintah Provinsi DKI Jakarta kepada KPAP DKI Jakarta. Pokja-pokja tersebut juga diharapkan memasukan kegiatan program pencegahan HIV/AIDS kedalam Dokumen Pelaksanaan Anggaran (DPA) sesuai dengan tupoksinya. Selain pokjapokja tersebut, KPAP DKI Jakarta juga melibatkan Lembaga Swadaya Masyarakat dalam melakukan penjangkauan populasi kunci, hal ini menjadi penting mengingat penularan terbesar HIV/AIDS adalah melalui hubungan seksual beresiko. Tata kelola kolaboratif pencegahan HIV AIDS juga melibatkan Lembaga Swadaya Masyarakat (LSM) dan Masyarakat melalui peran Warga Peduli AIDS. LSM memiliki peran untuk menjangkau populasi kunci dan memiliki kelebihan 
untuk memberikan respon terkait penanggulangan HIV dan AIDS (Alliance et al, 2007; Asthana and Oostvogels, 1996; Global Fund, 2014; WHO, 2001; UNAIDS, 2008).

Upaya penanggulangan HIV dan AIDS perlu menyentuh faktor sosial kemasyarakatan sehingga diharapkan dapat melibatkan masyarakat sebagai bagian pencegahan dan penanggulangan HIV dan AIDS. Peran masyarakat atau Warga Peduli AIDS adalah sebagai penggerak masyarakat untuk ikut dapat terlibat secara langsung dalam upaya pencegahan HIV dan AIDS di dalam lingkungan masyarakat. Upaya kolaboratif sudah dilakukan oleh pemerintah dan non pemerintah, namun setiap tahun jumlah kasus HIV AIDS terus mengalami peningkatan, sehingga hal ini mendorong peneliti untuk memfokuskan penelitian ini pada kajian proses collaborative governance. Proses collaborative governance merupakan hal yang penting untuk dianalisis dengan melihat pada indikator-indikator hubungan antar aktor didalamnya, sehingga akan didapat gambaran proses kolaborasi dalam pencegahan HIV AIDS di Provinsi DKI Jakarta.

\section{B. METODE PENELITIAN}

Penelitian ini merupakan penelitian deskriptif kualitatif, dengan teknik pengumpulan data melalui wawancara dan studi literatur. Pemilihan informan dilakukan secara purposive yaitu pihak yang dianggap representatif dengan pertimbangan relevansi antara pengetahuan dan informasi yang dimiliki informan dengan topik yang diteliti. Informan dalam penelitian ini yaitu
Sekretaris Komisi Penanggulangan AIDS Provinsi, Pengelola Program HIV AIDS Dinas Kesehatan Provinsi DKI Jakarta, Direktur Program Yayasan Kusuma Buana, Direktur Program Yayasan Pesona Jakarta, Direktur Program Yayasan Srikandi Sejati, dan Warga Peduli AIDS. Wawancara ini menggunakan alat perekam, catatan tertulis dan juga tinjauan literatur yang terkait dengan penelitian (Gabrielian, 1999:187). Data primer dan sekunder kemudian diolah dan dideskripsikan dalam bentuk narasi sesuai dengan kebutuhan data dalam pembahasan. Teknik pemeriksanaan keabsahan data yang digunakan melalui triangulasi, yaitu dengan memeriksa derajat kepercayaan, keteralihan, kebergantungan, dan kepastian (Moleong 2005:234). Pemilihan lokasi penelitian di Provinsi DKI Jakarta dikarenakan DKI Jakarta merupakan provinsi dengan jumlah kasus HIV AIDS yang dilaporkan tertinggi nasional.

\section{HASIL DAN PEMBAHASAN}

Tata kelola kolaboratif menekankan kepada adanya interaksi kolaboratif antara pemangku kepentingan dengan institusi publik dalam pengambilan keputusan yang berorientasi konsensus. Ansell dan Gash (2007) mendefinisikan tata kelola kolaboratif sebagai suatu bentuk susunan pemerintahan, dimana satu atau lebih instansi publik secara langsung berhubungan dengan pemangku kepentingan non negara dalam sebuah proses pengambilan keputusan yang formal, berorientasi pada konsensus, deliberatif, dan menuju pada formulasi atau implemetasi kebijakan publik, atau dapat pula berbentuk dalam manajemen program atau aset publik. Berdasarkan 
definisi tersebut, terdapat enam kriteria penting dari tata kelola kolaboratif, yatu :

1. Forum diprakarsai oleh badan atau institusi publik.

2. Peserta dalam forum merupakan termasuk aktor non pemerintah

3. Peserta terlibat langsung dalam pengambilan keputusan

4. Forum diorganisasikan secara formil dan bertemu secara kolektif

5. Forum bertujuan untuk membuat keputusan dengan consensus

6. Fokus kolaborasi pada kebijakan publik atau manajemen aset publik

Emerson dan Nabatchi (2015) menyatakan bahwa tata kelola kolaboratif adalah proses dan struktur pengambilan keputusan kebijakan publik dan manajemen yang melibatkan aktor secara konstruktif pada batas lembaga publik, pemerintahan dan masyarakat, swasta dan sipil untuk melaksanakan kepentingan umum yang tidak bisa diacapai jika hanya dilakukan satu pihak saja. Hal ini bisa dimaknai sebagai "Governance multipartner" yaitu tata kelola yang mampu mencakup kemitraan antar negara, swasta, serta masyarakat sipil dan masyarakat, serta bergabung dengan pengaturan pemerintah dan bersifat hybrid, seperti kemitraan publik-swasta dan kemitraan swasta dan sosial. Hal ini juga termasuk beberapa tindakan kolaboratif berbasis masyarakat yang terlibat dalam pengelolaan sumber daya bersama serta struktur kolaboratif antar pemerintah. Emerson dan Nabatchi (2015) memberikan definisi Collaborative Governance lebih luas lagi, yaitu tata kelola kolaboratif merupakan suatu proses dan struktur perumusan kebijakan publik, pengambilan keputusan dan manajemen publik yang melibatkan masyarakat dan badan publik, tingkatan pemerintah, swasta, dan ranah publik untuk mencapai tujuan publik (keseejahteraan) yang belum terselesaikan. Framework collaborative Governance memiliki berbagai dimensi, yaitu system context, Collaborative Governance Regime (CGR), dan dinamika kolaborasi seperti yang tergambar dalam gambar berikut :

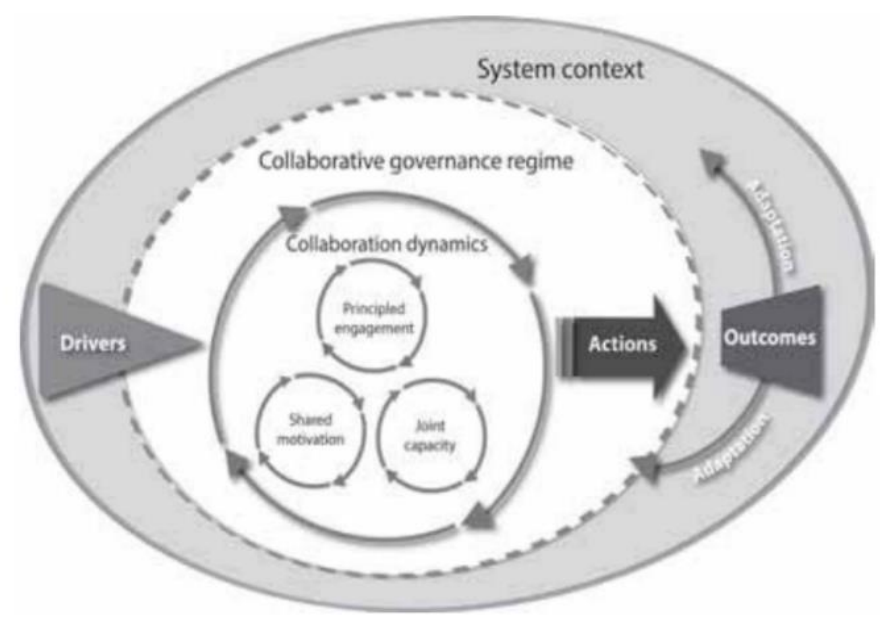

Gambar 1. Model Collaborative Governance menurut Emerson dan Nabatchi (2015) 


\section{Proses Collaborative Governance Pencegahan HIV di Provinsi DKI Jakarta}

Pencegahan HIV AIDS

membutuhkan peran antar stakeholder, sehingga perlu adanya kolaborasi antara pemerintah, LSM, dan Masyarakat. Proses kolaborasi merupakan inti dari kolaborasi yang menggambarkan secara terperinci mengenai komponen yang membentuk kolaborasi bersifat dinamis yang berputar dalam seluruh komponen dan saling mempengaruhi satu sama lain. a. Penggerakan Prinsip Bersama (Principled Engagement)

Keterlibatan berprinsip merupakan hal yang muncul seiring dengan waktu, dapat melalui dialog tatap muka, rapat umum, hubungan antar organisasi atau setting yang berbeda lainnya (Emerson dan Nabatchi, 2015). Melalui keterlibatan berprinsip ini, para aktor dengan latar belakang yang berbeda dapat bekerjasama untuk memecahkan masalah atau menciptakan suatu nilai. Emerson dan Nabatchi (2015) mengartikan keterlibatan berprinsip sebagai suatu komunikasi terbuka dan bersifat inklusif yang terjadi seiring berjalannya waktu melalui empat proses dasar, yaitu discovery (penemuan), definition (definisi), deliberation (musyawarah), dan determination (penetapan). Melalui proses tersebut maka kolaborasi dapat berjalan dan dapat mendorong motivasi dan aksi bersama untuk mencapai goal (tujuan). Hasil penelitian menunjukan bahwa dalam rapat rutin tahunan yang disebut dengan Rapat Kerja Daerah (Rakerda) KPA Provinsi DKI Jakarta turut mengundang lintas sektor, termasuk didalamnya LSM Peduli AIDS, perwakilan tokoh agama dan tokoh masyarakat, pokja, dan instansi lainya.
Tujuan dari Rakerda ini adalah sebagai sarana pertemuan formil, Focus Group Discussion (FGD), menerima masukan dari peserta terkait program pencegahan HIV AIDS, serta menghasilkan suatu kesepakatan bersama dengan pembentukan kesepakatan bersama. Keterlibatan berprinsip diartikan sebagai suatu ketaatan, komunikasi, dan bersifat inklusif. Pertemuan-pertemuan yang dilakukan menjadi sarana untuk saling menyampaikan informasi, kritik, dan saran untuk program pencegahan HIV kedepannya. Pertemuan rutin tidak hanya dilakukan melalui tatap muka, namun juga dilakukan melalui teknologi seperti email atau aplikasi chatting seperti whatsapp. Menurut Ansell \& Gash (2007) diskusi langsung berfokus kepada apakah pelaksanaan komunikasi rutin telah dilaksanakan, dimana komunikasi rutin digunakan untuk mengidentifikasi peluang untuk saling menguntungkan antar aktor serta kualitas deliberasi perlu memperhatikan adanya efektivitas komunikasi.

Dari informasi yang diperoleh melalui informan dapat diketahui bahwa sudah tercipta penggerakan prinsip bersama melalui forum pertemuan yang diadakan oleh KPA Provinsi DKI Jakarta yang dibentuk dan diperkuat melalui proses interaktif dari penemuan, pendefinisian, deliberasi dan determinasi dalam pencegahan HIV AIDS.

b. Motivasi Bersama (Shared Motivation)

Sikap saling percaya ditujukan Yayasan Srikandi Sejati, Yayasan Pesona Jakarta, dan Yayasan Kusuma Buana pada KPA Provinsi DKI Jakarta, melalui program yang melibatkan yayasan dan masyarakat, salah satu contohnya adalah program pemetaan populasi kunci yang dilakukan oleh KPA Provinsi DKI 
Jakarta dengan melibatkan yayasan untuk memetakan dan menganalisis wilayah yang terdapat populasi kunci. Hasilnya adalah Laporan Pemetaan Populasi Kunci Tahun 2014 dan Laporan Pemetaan Populasi Kunci Tahun 2016 yang sudah dipublikasi melalui website KPAP DKI Jakarta dan digunakan sebagai langkah awal melakukan intervensi program pencegahan HIV AIDS pada populasi kunci. Rasa saling percaya dapat muncul karena adanya pertemuan bersama yang diadakan oleh KPA Provinsi, selain itu melalui pelaksanaan program, ataupun evaluasi kegiatan, dan pengambilan keputusan.

Konsep motivasi bersama dari Emerson dan Nabatchi sedikit berbeda dengan konsep pemahaman bersama dari Ansell \& Gash, dimana Ansell \& Gash mendefinisikan pemahaman bersama sebagai upaya identifikasi nilai umum melalui adanya kesepakatan tentang definisi permasalahan. Melalui pertemuan bersama terjalin rasa percaya antara aktor satu dengan aktor lainnya. Membangun kepercayaan menjadi suatu hal yang penting, karena dengan adanya rasa percaya dapat memberikan manfaat kolaborasi antar aktor, misalnya pemerintah membutuhkan LSM dan masyarakat untuk melakukan penjangkauan populasi kunci dan masyarakat umum, LSM juga membutuhkan legitimasi untuk mendapatkan bantuan dari pemerintah. Setelah adanya rasa saling percaya antar aktor maka akan menghasilkan rasa saling memahami (shared understanding). Dari informasi yang diperoleh, dapat diketahui bahwa sudah tercipta motivasi bersama mengenai pencegahan HIV AIDS. Motivasi bersama tercapai melalui adanya kepercayaan bersama, saling memahami, legitimasi internal, dan komitmen. Namun, pada unsur saling memahami dan komitmen belum merata pada seluruh aktor, beberapa pokja melakukan kegiatan pencegahan HIV hanya jika diberikan anggaran melalui dana hibah KPA Provinsi DKI Jakarta, sedangkan sudah dua tahun ini pokja tidak diberikan anggaran terkait pencegahan HIV dan AIDS melalui KPAP, dan Pokja juga tidak menganggarkan untuk kegiatan pencegahan HIV di instansi masingmasing. Sedangkan LSM Peduli AIDS dan Warga Peduli AIDS tetap melakukan kegiatan pencegahan HIV AIDS dengan populasi sasaran seperti populasi kunci dan masyarakat umum. Hal ini akan mempengaruhi tahapan dinamika kolaborasi berikutnya yaitu kapasitas untuk melakukan aksi bersama.

c. Kapasitas Untuk Melakukan Aksi Bersama (Capacity for Joint Action)

Tujuan kolaborasi adalah untuk menghasilkan hasil yang diinginkan bersama yang tidak dapat diselesaikan secara terpisah. Himmelman (1994) dalam Emerson dan Nabatchi (2015) menjelaskan bahwa kolaborasi terlibat dalam aktivitas bersama untuk meningkatkan kualitas kapasitas dalam mencapai tujuan bersama. Kapasitas untuk melakukan aksi bersama merupakan aspek ketiga dari dinamika kolaborasi yang merupakan hasil dari keterlibatan berprinsip dan motivasi bersama. Kapasitas untuk melakukan aksi bersama terdiri dari elemen seperti prosedur dan kesepakatan institusi (procedural and institutional arrangements), kepemimpinan (leadership), pengetahuan (knowledge), dan sumber daya (resources). 
Dalam kolaborasi pencegahan HIV AIDS, melibatkan kelompok kerja, Lembaga Swadaya Masyarakat, dan masyarakat yang dikoordinasikan melalui lembaga KPA Provinsi ataupun KPA Kota Administrasi. Prosedur dan kesepakatan institusi kelompok kerja diformalisasikan melalui Surat Keputusan Ketua Komisi Penanggulangan AIDS Provinsi Daerah Khusus Ibukota Jakarta Nomor 031 Tahun 2009 tentang Penetapan Kelompok Kerja (Pokja) Program Penanggulangan HIV dan AIDS.

Landasan hukum tersebut tidak sepenuhnya dibuat dalam proses kolaborasi, namun merupakan penurunan dari Pergub Nomor 56 Tahun 2005 tentang Organisasi dan Tata Kerja KPA Provinsi DKI Jakarta, yang diperbaharui melalui Pergub Nomor 231 Tahun 2015, dimana dalam satu pasal dikemukakan bahwa untuk membantu pelaksanaan tugas KPAP maka ketua KPAP dapat membentuk kelompok kerja KPAP yang jumlahnya disesuaikan dengan kebutuhan dimana susunan dan uraian tugas kelompok kerja ditetapkan oleh Ketua KPAP. Sedangkan, keterlibatan masyarakat dalam program pencegahan HIV AIDS dikuatkan melalui Surat Keputusan dari Walikota dan SK Sekretaris KPA Kota Administrasi. Pembentukan prosedur dan kesepakatan institusi ini telah terbentuk sesuai dengan yang dikemukakan oleh Emerson dan Nabatchi (2015) yaitu adanya struktur berjejaring dan self managed system.

$$
\text { Ketika suatu kelembagaan }
$$
kolaboratif sudah terbentuk maka diperlukan konsep kepemimpinan kolaboratif. Kepemimpinan merupakan suatu kapabilitas untuk mendorong arah kesamaan visi, dimana pemimpin merupakan individu yang membantu individu lain untuk mencapai tujuannya (Kreitner \& Kinicki, 2014). KPA, baik KPA Provinsi maupun KPA Kota Administrasi merupakan pemimpin kolaborasi yang berfungsi sebagai koordinator. Namun tiap anggota merupakan pemimpin dalam melaksanakan program pencegahan HIV. Pentingnya kepemimpinan dalam tata kelola kolaboratif secara jelas digambarkan oleh Ansell \& Gash (2008). Kepemimpinan dapat menjadi pendorong kolaborasi, unsur utama dalam kolaborasi itu sendiri, dan pertumbuhan yang signifikan dari kolaborasi. Termasuk didalamnya peran pemimpin sebagai pendukung (sponsor), fasilitator, mediator, perwakilan dari organisasi, advokasi, dan peran lainnya. Pada proses kolaborasi, pengetahuan banyak didistribusikan melalui pertemuan bersama. Pertemuan tersebut terdapat penyampaian hasil capaian yang dilakukan oleh para aktor, yang kemudian menjadi bahan diskusi. Proses ini dapat membangun pengetahuan tiap aktor. Tiap aktor memiliki karakteristik pengetahuan yang berbeda-beda, misalnya Dinas Kesehatan melalui sistem pelaporan ODHA dari setiap puskesmas dan layanan kesehatan, LSM dengan laporan pemetaan populasi kunci, serta pokja yang menyampaikan laporan terkait program dan cakupannya di instansi masing-masing. Namun, distribusi pengetahuan ini mengalami kendala antara lain perwakilan aktor berganti-ganti terutama pada Pokja atau instansi karena mutasi ataupun lain hal sehingga aktor yang menghadiri pertemuan kolaborasi pun tidak selalu sama. 
Dari informasi yang diperoleh
dapat diketahui bahwa kapasitas melakukan aksi bersama sudah berjalan melalui kegiatan yang dilakukan bersama melalui prosedur dan kesepakatan bersama seperti pelaksanaan Voluntary Counseling Test (VCT) dan sosialisasi pencegahan HIV AIDS pada peringatan Hari AIDS Sedunia (HAS), namun terdapat beberapa permasalahan yang terjadi terutama terkait sumber daya pendanaan yang mempengaruhi kegiatan pencegahan HIV AIDS pada pokja, sedangkan hal ini tidak memiliki pengaruh terhadap LSM dan masyarakat karena sumber pendanaan mereka secara mandiri tidak seperti pokja yang pendanaan kegiatannya melalui dana hibah KPA Provinsi. Kapasitas aksi bersama sangat dipengaruhi dari keterlibatan berprinsip dan motivasi bersama, dimana terdapat kelemahan pada unsur pemahaman bersama pada pokja yang tidak menganggarkan kegiatan melalui instansinya dan mengandalkan melalui dana hibah dari KPA Provinsi. Kesimpulan dari dinamika kolaborasi ini adalah berjalan atau tidaknya dinamika ditentukan oleh tiga unsur yaitu penggerakan prinsip bersama, motivasi bersama, dan kapasitas untuk melakukan aksi bersama. Dinamika kolaborasi berbentuk siklus yang didalamnya terdiri dari komponenkomponen yang saling mempengaruhi jalannya kolaborasi.

\section{PENUTUP}

Berdasarkan hasil analisis yang diuraikan pada pembahasan, maka dapat disimpulkan bahwa proses collaborative governance pada pencegahan HIV AIDS di Provinsi DKI Jakarta secara umum sudah memenuhi konsep dinamika kolaborasi Emerson dan Nabatchi (2015). Namun, terdapat temuan penelitian yang membedakan antara konsep dan proses collaborative governance pencegahan HIV AIDS antara Pemerintah, Lembaga Swadaya Masyarakat, dan Masyarakat di Provinsi DKI Jakarta, yaitu Unsur determinasi atau hasil kesepakatan bersama yang difasilitasi dalam pertemuan formil masih terbatas, pertemuan lebih banyak membahas mengenai teknis program kegiatan pencegahan HIV AIDS. Mengacu kepada teori Collaborative Governance Emerson dan Nabatchi (2015), determinasi merupakan salah satu unsur yang juga mendorong shared motivation atau motivasi bersama, selain itu Komitmen pencegahan HIV AIDS lebih kuat pada Dinas Kesehatan, LSM, dan Masyarakat saja, sedangkan komitmen dari pokja atau SKPD dirasa masih kurang, hal ini diindikasikan dengan tidak adanya kegiatan pencegahan HIV AIDS pada pokja selama dua tahun terakhir. Menurut teori collaborative governance Emerson dan Nabatchi (2015) komitmen bersama merupakan salah satu unsur pendorong kapasitas melakukan aksi bersama. Secara keseluruhan, seluruh dimensi collaborative governance dapat memberikan pengaruh bagi dimensi lainnya, sehingga apabila salah satu dimensi tidak berjalan maka dimensi lainnya juga akan mengalami kendala. 
DAFTAR PUSTAKA

Agbodzakey, James K. 2015. Quantitative Evidence of Collaborative Governance of Broward and Palm Beach Counties HIV Health Services Planning Councils in Two Different Legislative Cycles. International Journal of Current Advanced Research, 520-530, December 2015.

Ansell, Chris dan Alison Gash. 2007. Collaborative Governance in Theory and Practice, Journal of Public Administratiom Research and Theory, Advance Access Published, 18: 543 - 571, November 13.

Australian Aid. 2015. Kebijakan HIVAIDS dan Sistem Kesehatan di Indonesia. Hasil penelitian kerjasama Australian Aid dengan Pusat Kebijakan dan Manajemen Kesehatan Fakultas Kedokteran UGM.

Emerson, Kirk dan Tina Nabatchi. 2015. Collaborative Governance Regimes. Washington DC : Georgetown University Press.

Emerson, Kirk, Tina Nabatchi dan Stephen Balogh. 2012. An Integrative Framework for Collaborative Governance. Journal of Public Administration Research and Theory, May, Vol. 22:1-29.

Gabrielian, Vatche. 1999. Qualitative Research Methods: An Overview dalam Gerald J. Miller \& Marcia L. Whicker. Handbook of Research Methods in Public Administration, New York:Marcel Dekker. 167-2015.
Komisi Penanggulangan AIDS Provinsi DKI Jakarta. 2017. Paparan: Program Penanggulangan HIV dan AIDS Serta Situasi Epidemi HIV dan AIDS di DKI Jakarta. Komisi Penanggulangan AIDS Provinsi DKI Jakarta.

Lexy, J. Moleong. 2005. Metodologi Penelitian Kualitatif. Bandung: Remaja Rosdakarya.

Mayer, Kenneth H dan Hank F. Pizer. 2009. HIV Prevention : $a$ Comprehensive Approach. London: Academic Press.

Osborne, Stephen. P. 2010. The New Public Governance? Emerging Perspective on the Theory and Practice of Public Governance, New York : Routledge.

World Health Organization. 2017. Kajian Nasional Respon HIV di Bidang Kesehatan Republik Indonesia. Laporan WHO untuk Indonesia.

Peraturan Daerah Provinsi DKI Jakarta Nomor 5 Tahun 2008 Tentang Penanggulangan HIV/AIDS di Provinsi DKI Jakarta

Peraturan Gubernur Provinsi DKI Jakarta Nomor 26 Tahun 2012 tentang Komisi Penanggulangan AIDS Provinsi dan Kota/Kabupaten Administrasi

Peraturan Gubernur Provinsi DKI Jakarta Nomor 231 Tahun 2015 tentang Komisi Penanggulangan AIDS Provinsi dan Kota/Kabupaten Administrasi 
Jurnal Administrasi Negara

ISSN : 2598-4039 (Online)

ISSN : 2302-2231 (Print)

Agung Rheza Fauzi, Amy Yayuk Sri Rahayu Program Studi Administrasi dan Kebijakan Publik Fakultas Ilmu Administrasi Universitas Indonesia

Keputusan Wakil Gubernur Provinsi DKI

Jakarta selaku Ketua Komisi

Penanggulangan AIDS Provinsi DKI

Jakarta Nomor 62/KPAP-

DKI/VIII/07 tentang Penetapan

Kelompok Kerja (Pokja) Program

Penanggulangan HIV/AIDS di

Provinsi DKI Jakarta. 